\title{
Žákovské prekoncepty jako konstitutivní prvek výuky mateřského jazyka ${ }^{1}$
}

\author{
Stanislav Štěpáník ${ }^{\text {a }}$, Jan Slavík ${ }^{\mathrm{b}}$ \\ ${ }^{a}$ Univerzita Karlova, Pedagogická fakulta, Katedra českého jazyka \\ b Univerzita Karlova, Pedagogická fakulta, Katedra primární pedagogiky
}

Redakci zasláno 23. 2. 2016 / upravená verze obdržena 7. 10. 2016 /

k uveřejnění přijato 10.11. 2016

\begin{abstract}
Abstrakt: Cílem této empirické studie je: (1) představit žákovský prekoncept jako konstitutivní prvek výuky mateřského jazyka, (2) ukázat na konkrétním př́kladu větného členu (přívlastku), že pojetí žákovského prekonceptu jako klíčové determinanty výuky je nejen opodstatněné, ale přímo nutné; (3) uvést návrh, kudy by se další výzkum i snahy o zlepšování výuky v této oblasti mohly ubírat. V první části jsou vymezeny základní pojmy - představa, prekoncept a koncept - a je analyzováno jejich místo ve výuce mateřského jazyka. Následně se text věnuje kritickým místům ve výuce českého jazyka a české syntaxe, další část prezentuje samotný výzkum. Metodou stratifikovaného náhodného výběru byl vytvořen vzorek žáků 1. ročníku střední školy, u nichž byl metodou individuálního řízeného rozhovoru nad speciálně designovanými cvičeními zjištován žákovský prekoncept přívlastku. Z výsledků vyplývá, že žáci disponují prekonceptem přívlastku a i hưře prospívající žáci jsou schopni tento prekoncept verbalizovat a přesně ho popsat, avšak po zavedení terminologie se u některých projevuje blok vyvolaný edukací a dochází ke střetu přirozeného vnímání jazyka a gramatického popisu. Zároveň se ukazuje, že po přechodu na rovinu školních znalostí žáci začnou o jazykových jevech přemýšlet jinak - jejich spontánní uvažování je zastaveno a nastupují nevhodné zmechanizované postupy, které žákům škola vnutila. Studie rovněž upozorňuje na desetiletí přetrvávající problém - výuka zavádí terminologii př́liš brzy, aniž by navazovala na přirozenou jazykovou kompetenci a komunikační zkušenost žáků. I přes nedostatečné ukotvení základních znalostí pak postupuje dál, čímž se vytváří bludný kruh neúspěchu.
\end{abstract}

Klíčová slova: žákovská představa, prekoncept, koncept, didaktika, český jazyk, mateřský jazyk, syntax, větný člen, přívlastek

1 Tento text byl zpracován v rámci projektů PRIMUS/HUM/19 Didaktika českého jazyka $v$ současném vzdělávacím kontextu a Program rozvoje vědních oblastí na Univerzitě Karlově. Autoři děkují za poskytnutou podporu; rovněž děkují recenzentům za poskytnuté připomínky. 
Sjednocení hledisek poznávací perspektivy oboru a perspektivy žáka při didaktickém zprostředkování vzdělávacího obsahu žákovi představuje klíčový problém současného bádání oborových didaktik. Učitel se ve své činnosti pohybuje mezi oběma póly a je podstatné, aby byl schopen do výuky oba zahrnout - „aby dokázal nahlédnout a zpracovat obsah výuky jak ze strany nároků oboru, tak s ohledem na nároky žáka“ (Slavík \& Janík, 2005, s. 339). Propojování psychodidaktické a ontodidaktické dimenze $\mathrm{v}$ pedagogickém výzkumu se proto stalo významným zdrojem poznatkové báze oborových didaktik, a to i s ohledem na fakt, že jedním z hlavních proudů současné moderní kultury vyučování a učení je konstruktivismus (Janík, 2013), jenž žákovskou perspektivu považuje za jedno ze základních východisek vzdělávacího procesu.

Subjektivní uchopení obsahu žákem se tak stává principiálním také pro projektování kurikula - např v modelu didaktické rekonstrukce (Jelemenská, Sander, \& Kattmann, 2003). Nároky na učitele českého jazyka jsou v tomto směru o to větší, že žák (implicitní) znalostí jazyka, tedy objektem i instrumentem výuky, disponuje již v okamžiku vstupu do školní edukace, a to takřka v celé jeho širri, nebot' formální výstavba řeči šestiletého dítěte je blízká řeči dospělého člověka (Jelínek, 1979).

Následující text navazuje na uvedená témata a zabývá se otázkami, které psychodidaktická dimenze klade pro ontodidaktický přístup $\mathrm{k}$ učivu. Zároveň se snaží dokázat, že zohlednění žákovské perspektivy v didaktickém př́istupu k vzdělávacímu obsahu je při plánování výuky stěžejní, přitom však doposud opomíjené.

\section{Vymezení základních pojmů}

K rozpracování uvedených témat je nejprve třeba objasnit klíčové pojmy, s nimiž pracujeme a jež umožňují analyzovat a vyložit vztah mezi psychodidaktickou a ontodidaktickou stránkou práce učitele. Terminologie v oblasti žákovského (před)poznání obsahu je značně rozkolísaná, primárně však jde o vztah tř́ základních pojmů, resp. termínů: predstava, prekoncept a koncept. V následujícím výkladu je definujeme jednak transdidakticky a jednak v kontextu didaktiky českého jazyka.

Představu chápeme jako „subjektivní moment existence obsahu ve vědomí (Janík \& Slavík, 2009, s. 121). Je místně a časově lokalizovaná a předbíhá 
aktuálnímu užití jazykového prostředku. Rodilý mluvčí na základě své komunikační zkušenosti ví, které jazykové prostředky v dané komunikační situaci pro vyjádření zamýšleného obsahu a komunikačního záměru vybrat. Představa aktualizuje jeho schopnost v takové situaci „mluvit a rozumět“.

Samotný pojem představa, jak jej zde užíváme, ale nedovoluje vysvětlit obecnou a na rozdíl od představy relativně stabilnější dispozici, kterou subjekt musí mít, aby mohl jazyk užívat. K tomuto vysvětlení slouží jiný pojem - pojem prekoncept (viz níže). ${ }^{2} S$ ohledem na něj můžeme představu vyložit jako mentální spojnici mezi prekonceptem a jazykovým jednáním: řečí. Obecně vzato, představa je svorníkem mezi subjektivním myšlením, jednáním a intersubjektivním obsahem zakotveným v prekonceptu ${ }^{3}$ (dle Slavík, 2014). Představa tedy díky prekonceptu umožňuje „vidět" nebo „dělat" uvnitř mysli to, co lze nakonec i „předvést“ v jednání. Konkrétní výpověd' je pak konkrétní subjektivní reprezentací významové a výrazové („tvarové“) struktury představy pro uskutečnění určitého komunikačního záměru - obecněji: pro určité jazykové jednání.

Aby mohl mluvčí vyjádřit, co chce, potřebuje disponovat znalostí jazykových prostředků a způsobu fungování těchto prostředků v jazykovém systému. Tuto dispozici jsme výše označili jako prekoncept. Jazykový prekoncept rodilého mluvčího je strukturní složkou jeho (zprvu jen implicitní) znalosti mateřského jazyka, tj. znalosti encyklopedie (slovní zásoby se soustavou významů) a jazykových pravidel či zákonitostí. Pouze díky svým jazykovým prekonceptům je subjekt schopen komunikovat - více či méně adekvátně produkovat a recipovat př́slušný obsah (přičemž správnost je určena intersubjektivní shodou a ideálním měřítkem při zacházení s obsahem, tedy objektivitou - srov. Janík \& Slavík, 2009, s. 122).

Jazykový prekoncept vzniká již od raného dětství jedince jako „koncentrovaná“ zkušenost s užíváním jazyka v komunikačních situacích, do nichž se

2 Volně zde jde o analogii Chomského rozlišení jazykové kompetence jako jazykové způsobilosti / implicitní znalosti jazykového systému a jazykové performance jako konkrétní realizace jazyka - ještě lépe snad pak jeho doplněný koncept I-jazyka a E-jazyka, kde se I-jazyk vztahuje k internalizovanému jazyku, jenž je jazykem v mysli mluvčího, zatímco E-jazyk jako externalizovaný jazyk reprezentuje konkrétní pozorovatelný jazykový „výstup“ mluvčího.

3 Např. hudební představa spojuje hudební obsah intersubjektivně sdílený prostřednictvím hudební notace (notového záznamu hudebního díla) nebo poslechu hudebního díla s prekonceptem a hudebním jednáním člena orchestru (Slavík, 2014). Analogickou funkci má jazyková představa při čtení románu nebo poslechu mluvené řeči. 
dítě dostává. Jak popisuje Průcha (2011, s. 51), nejprve si dítě osvojuje fonologický aparát mateřského jazyka, souběžně s tím primární slovní zásobu, ve třech letech pak začíná osvojování gramatického (tj. morfologického a syntaktického) systému jazyka, prudce se rozvíjí slovní zásoba a také oblast pragmalingvistických funkcí jazyka. Průcha gramatickou kompetenci dítěte (t). „soubor znalostí a dovedností týkajících se gramatického systému určitého jazyka“) označuje jako kompetenci „neuvědomovanou“ (2011, s. 51).

Prekoncept tak představuje určité „jazykové povědomí“ jedince, které má složku kognitivní, afektivní a konativní - podle toho by bylo možné rozdělit strukturu jazykového prekonceptu na jazykový rozum, jímž jazyk reflektujeme (složka kognitivní), jazykový cit, jímž jazyk „procitujeme“ (složka afektivní) a jazykové jednání, jímž jazyk „užíváme, realizujeme“ (složka konativní; Dolník, 2010, s. 26). Prekoncept je tedy individuální disponovanost k užívání jazyka a v obecnějším (transdidaktickém) smyslu k užívání jakéhokoliv lidmi sdíleného kulturního systému znalostí (explicitních, ale neméně též implicitních). To znamená, že kvalita prekonceptu bezprostředně rozhoduje o kvalitě odpovídajícího typu „funkční gramotnosti“ libovolného druhu (jazykovou počínaje a třeba finanční konče).

$\mathrm{V}$ tomto směru lze $\mathrm{v}$ didaktice mateřského jazyka hovořit o úzkém vztahu mezi dovednostmi (čtením, psaním, mluvením a nasloucháním; v moderní terminologii „gramotností"), které jsou podmíněné utvářením představ, a více či méně uvědomělou znalostí jazykového systému, založenou na prekonceptech. Právě na základě tohoto vztahu existuje v didaktice českého jazyka tradiční předpoklad, že systematické jazykové vyučování je důležitým faktorem pro úspěšnou práci s textem - at' už na úrovni recepce nebo produkce. ${ }^{4}$

4 Zmíněnému předpokladu se věnuje velká pozornost také v zahraničí - srov. různé postavení jazykového vyučování u nás a např̀ v anglicky mluvících zemích a mnohdy s tím spojené bouřlivé diskuze odborné i laické veřejnosti. Otázce je zasvěcená např. publikace redigovaná T. Lockem (2010); ten v úvodu ke knize píše: "As social players in these situations [social occasions wherein textual acts of textual production and textual interpretation and response are situated - pozn. S. Š.], we are called upon to make choices in respect of how we read situations and how we compose our textual acts. Explicit language (or grammatical) knowledge enhances language-users in these choices" (s. 8). [Jako po sociálních aktérech těchto situací (sociálních situací, v nichž jsou situovány akty produkce a interpretace textů a interakce s nimi - pozn. S. Š.) se po nás požaduje, abychom činili výběr v kontextu toho, jak dané situace čteme a jak komponujeme vlastní textové akty. Explicitní (nebo gramatická) znalost jazyka v tomto směru zvětšuje možnosti uživatelů jazyka.] (Locke, 2010, s. 8; překlad S. Š.) 
Ze speciálního pohledu didaktiky jazyka je prekonceptem dispozice mluvčího k vlastnímu jazykovému jednání, k zpětnovazebním korekcím a rovněž predispozice uživatele k porozumění jazyku na metaúrovni. Díky prekonceptům je mluvčí schopen posoudit funkci a význam jazykového prostředku a vystihnout podstatu daného jevu (srov. Štěpáník, 2014). Vztah prekonceptu a představy lze pak vystihnout následovně: v konkrétní promluvě se prekoncept aktualizuje prostřednictvím představy, která formuje obsah sdělení do podoby nakonec vyjádřené jazykovým jednáním.

Jazykový prekoncept není fenomén nový - objevil se již v Tezích Pražského lingvistického kroužku na zasedání roku 1929, i když tehdy pod označením jazyková pohotovost (Vachek, 1970). Horecký (1991) užívá označení jazykové vědomí, Kucharská (2012) přirozeně rozvinuté jazykové dovednosti, Höflerová (2012) aktivně užívané dovednosti. ${ }^{5}$ My tento fenomén nazýváme přirozená jazyková kompetence (Štěpáník, 2015).

Ačkoliv se vymezení prekonceptu u různých autorů liší, u všech jde o subjektivní znalost jazyka založenou na dosavadní komunikační zkušenosti mluvčího. Tato subjektivně uchopená „suma jazyka“ - jazykových prostředků, významů a struktur - je však zprvu vědomě neorganizovaná, žák není schopen o ní přemýšlet na úrovni metajazyka, a jeho prekoncepty se proto nemohou stát uvědomělým a intersubjektivně sdíleným nástrojem myšlení (Höflerová, 2015). Žákovy znalosti jsou neuvědomělé (implicitní): žák „umí jazyk“, ale nezvládá „porozumění jazyku“. Proto své jazykové jednání nedovede ostatním uživatelům jazyka přesvědčivě vysvětlit, ani neumí zdůvodňovat (ostatním, ale především sám pro sebe) užití určitých jazykových prostředků. Právě tady jde o ony možnosti jazykového systému, jak o nich hovoří Locke (2010, viz výše) nebo také Zimová (2011/2012).

Je proto úkolem školy převádět neuvědomělé (implicitní či tacitní) znalosti na znalosti uvědomělé, aby byl žák jako uživatel jazyka schopen zdůvodněně vybírat ze složitého inventáře jazykových prostředků fungujících jako systém ty, které nejlépe slouží jeho komunikačním potřebám a nejlépe vyhovují jeho komunikačnímu záměru. Žák je pak schopen na základě poznání jazyka vědomě rozpoznávat hodnoty vlastního užívání jazykových prostředků. Höflerová (2015, s. 534) to trefně nazývá „znovuobjevováním“ jazykového

\footnotetext{
Z variantnosti označení vyplývá, že jazykový prekoncept je značně komplexní, nebot' skutečně zahrnuje všechny tři dimenze prekonceptu, jak jsme je zmínili výše - kognitivní, afektivní i konativní. Má tedy povahu složitých struktur.
} 
systému. Jinými slovy: ve škole se implicitní znalost jazyka stává zjevnou, a tedy vědomě a intersubjektivně postihnutelnou poznáním oboru - lingvistiky. Díky porovnávání představ a prekonceptů s poznatky, které předkládá učitel, žák objevuje koncepty jazyka.

Intersubjektivně sdílená část (součást) obsahu jazyka, která je nezbytným předpokladem pro existenci subjektivních prekonceptů, je označována jako koncept. ${ }^{6}$ Koncept je tedy určitá obsahová jednotka, která „odráží podstatné znaky velké skupiny věcí nebo jevü“ (Jelínek, 1979, s. 61) a které lze porozumět pouze prostřednictvím „zobecnění podstatných vlastností daného jevu skutečnosti“ (Čechová \& Styblík, 1998, s. 44).

Koncept je součástí pravidelnosti světa a jeho vymezením se v didaktice snažíme vystihnout fakt, že všichni, kdo mají zvládnout určitý obsah, musí mít nějakou společnou dispozici: prekoncept daného konceptu. $V$ jazyce se jedná o společnou dispozici všech mluvčích správně používat jazyk při produkci i recepci. To znamená, že všichni mluvčí mají přístup ke společnému „ideálu jazyka“ - konceptu - nicméně každý jen „za sebe“, tj. prostřednictvím svého prekonceptu. Záleží na kvalitě prekonceptu (ve spojení s představami a s dovedností jednat), do jaké míry se ten či onen subjekt vyrovnává s nároky, které jsou na něj kladeny konceptem. ${ }^{7}$

Koncept je vědomě uchopitelný a intersubjektivně vysvětlitelný prostřednictvím oborového odborného jazyka - v našem př́ípadě lingvistiky. Pro lingvodidaktiku je přitom důležité, že každý rodilý mluvčí prostřednictvím svých prekonceptů intuitivně ovládá jazykové koncepty - umí vytvářet představy konkrétních jazykových konstrukcí pro splnění svého komunikačního záměru v určité komunikační situaci. Přitom se ale vůbec nemusí orientovat v lingvistice. Dokonce, jak se ukáže v dalším textu, nedobře zvládnutá lingvistická

6 V uvedeném pojetí jsou pojmy koncept (intersubjektivně sdílený) a prekoncept (míra subjektivního uchopení konceptu) definovány na základě své vzájemné podmíněnosti, nikoliv jako izolované jednotky nebo samostatně existující hodnoty. Proto také koncept (a jistě ani prekoncept) nemůže být totéž, co lingvisticky chápaný pojem, přesto se ale o něm prostřednictvím odpovídajícího pojmu dorozumíme (srov. Slavík, Chrz, \& Štech, 2013, s. 64-65). Kupř. žák hry na kytaru v ZUŠ disponuje určitou kvalitou prekonceptů hudby, které mu umožňují utvářet si hudební představy a „hudebně jednat", tj. v tomto případě hrát na kytaru. Naráží však přitom na nedostatky v dovednosti, které odstraňuje cvičením. Tím se současně zlepšuje kvalita jeho představ a prekonceptů. Obdobně je tomu v jazykovém vyučování např žák, který píše slohovou práci, disponuje určitou kvalitou prekonceptů jazyka, což mu umožňuje utvářet si jazykové představy a zároveň „,jazykově jednat“. Jazykové vyučování mu pak napomáhá rezervy, které doposud v jeho jazykové výbavě jsou, překonat. 
znalost může i rodilému mluvčímu různými způsoby intuitivní zacházení s jazykem komplikovat.

Pokud však je lingvistická znalost funkční („funkční gramotnost“), lingvistické poznání mluvčímu poskytuje interpretační a explikační rámec, díky němuž dochází k propojení myšlení jedince (tedy prekonceptů a představ) s oborem a jeho prostřednictvím s jazykem (s koncepty). Koncepty v takovém pojetí pak umožňují mluvčímu jazykové konstrukce nejen tvořit a užívat „správně“, ale rovněž udávat důvod $y$ „správného“ tvoření a užívání jazykových prostředků a vysvětlovat je ostatním mluvčím. Lingvistika tak uživatelům jazyka dává možnost postihnout jazykové koncepty prostřednictvím odborného jazyka a tím je uchopit metakognitivně, čímž se následně stávají prostředkem myšlení, nebot' „myšlení se uskutečňuje v pojmech“ (Slavík, 2014). V tomto směru je užitečné připomenout zásadní teorii J. Jelínka, totiž že myšlení a jazyk se rozvíjejí v jednotě - „nelze rozvíjet jazyk, aniž bychom rozvíjeli myšlení, nelze rozvíjet myšlení, aniž bychom rozvíjeli jazyk." (Jelínek, 1979, s. 61).

Ve výuce je koncept obecným nutným předpokladem pro utváření žákovy explicitní (deklarativní) znalosti v podobě pojmů, resp. termínů (příslušného oboru). Termíny jsou pojmy, které užívá určitý obor „lege artis“, tj. podle nejlepší dosažené úrovně svého poznání (srov. Slavík et al., 2015). Máme tím na mysli, že koncept je vyložen prostřednictvím svého uchopení v pojmech jazyka a/nebo v termínech oboru. Tímto způsobem se provazuje neuvědomělá intuitivní složka subjektivního prekonceptu s predstavou o něm samém ${ }^{8}$ a následně s jeho uvědoměle sdělitelnou stránkou. Přitom ale hrozí nebezpečí, že se ve výuce uvědomělá a neuvědomovaná stránka prekonceptu navzájem odtrhnou a dojde k didaktickým formalismům, které Janík a kol. (2013, s. 236) označují jako „odcizené“ nebo „utajené“ poznávání.

E. Hájková a kol. (2013, s. 10) pro žákovu „fixaci komunikační zkušenosti s daným [lingvistickým] pojmem“ zavádí termín pseudopojem. V tomto př́ipadě však nejde o jakousi naivní představu konceptu/pojmu samého, ale jde o kvazi-termín (tj. termín subjektivní teorie), který žák vytváří pro svou aktuální potřebu označit koncept (který je založen na žákově prekonceptu).

\footnotetext{
Žák kupř. používá koncept, který se v lingvistice nazývá „přívlastek“, aniž o něm ví a uvědoměle o něm uvažuje. Jakmile však získá k dispozici pojem a/nebo termín „přívlastek“ a rozumí jeho obsahu, dostane příležitost si přívlastek vybavit v představách jako součást svého jazykového jednání, vracet se k němu v myšlení, rozpoznávat ho opakovaně uvnitř reálné řeči, efektivně ho používat ve své komunikaci apod.
} 
Přiléhavější označení by tedy dle našeho názoru bylo spíše „pseudotermín“. Zachováme-li však terminologii Hájkové, dle autorky učitel žákovy pseudopojmy překrývá, přepisuje, nahrazuje pojmy lingvistickými. Ovšem „staví-li školní edukace na jiném základě než na žákovském pseudopojmu, staví v podstatě ,hrad na písku! Jazyková informace neukotvená v žákovském prekonceptu zůstane ve verbalizované formě, kterou učitel žáku předložil." (Hájková, 2013, s. 10). Gramatika je totiž „logikou“ jazyka, nikoliv myšlení (Jelínek, 1979, s. 62), a proto se lingvistické poznání neodráží v myšlení žáka - a tedy v kvalitě jeho gramotnosti - automaticky. Toto poznání tak představuje základní výzvu mluvnického vyučování.

\section{Oborovědidaktické ukotvení studie - výzkumy na spojnici psycho- a ontodidaktiky}

Debata týkající se pojetí výuky mateřského jazyka u nás je aktuální již po desetiletí, lze říci i staletí (srov. Šmejkalová, 2010). V centru těchto diskuzí vždy vedle morfologie stála syntax jako základní disciplína popisu jazyka i jazykové výuky. $Z$ didaktického hlediska se jedná o vysoce relevantní obsah - nejenže je zásadní pro rozvoj myšlení žáků (srov. mj. Svoboda, 1975; Čechová \& Styblík, 1998; Dvořák, 1997/1998; Svobodová, Jandová, \& Hubáček, 2002; Nippold et al., 2005, 2014), ale rovněž pro rozvoj jejich komunikačních dovedností, nebot' „zvládnutí stavby věty a souvětí je jedním z předpokladů zvládnutí stavby textu" (Čechová \& Styblík, 1998, s. 139; srov. též Gaux \& Gombert, 1999).

Pouze výběrově zmiňme problémy, jimž současná výuka češtiny ve školách čelí: komunikační dovednosti žáků nejsou dobré (srov. Kostečka, 2012a, 2012b; Čechová, 2013/2014), čtenářské dovednosti se zhoršují (srov. Palečková, Tomášek, \& Basl, 2010), předmět je jedním z nejméně oblíbených ze všech školních předmětů, což je navíc dlouhodobý fenomén (Pavelková, Škaloudová, \& Hrabal, 2010). Lze předpokládat, že zmíněné problémy se vztahují také na výuku syntaxe, nebot' existuje úzký vztah mezi syntaktickým povědomím (syntactic awareness - Gaux \& Gombert, 1999, s. 170, tedy syntaktickými prekoncepty) a receptivními a produktivními dovednostmi žáka (Svoboda, 1977; Čechová \& Styblík, 1998; Gaux \& Gombert, 1999; Dean, 2003). 
Kritická místa ve výuce syntaxe lze shrnout do následujících bodů:

1) učivo je atomizováno, nevhodně strukturováno, často neodpovídá aktuální kognitivní vyspělosti žáků, výuka určitých partií učiva doposud nebyla dostatečně zdůvodněna (srov. Čechová, 2011/2012; Zimová, 2005/2006; také mnozí další dříve - např. Chlup, 1958; Průcha, 1978, 1983);

2) mnohé výukové metody jsou používány nevhodně a bezúčelně (např. metoda jazykového rozboru, základní metoda syntaktické výuky - $\mathrm{k}$ tomu např. Čechová, 2011/2012; Hrbáček, 1999/2000; Zimová, 2011/2012; a opět mnozí další předtím - např. Hausenblas, 1965/1966);

3) aplikace poznatků je zmechanizovaná a formální (srov. mj. Adam et al., 2010/2011; Šalamounová, 2013; Štěpáník, 2014, 2016; mnozí další již dřive - např. Jelínek, Těšitelová, \& Styblík, 1957);

4) žáci nechápou podstatu učiva, nevědí, proč si mají dané poznatky osvojit, didaktické postupy komplikují rozvoj myšlení žáků a jejich porozumění systému jazyka - jazyk není prezentován jako systém, ale jako soubor izolovaných poznatků (srov. např. Rysová, 2005/2006; Zimová, 2005/2006);

5) výuka syntaxe (zvláště pak oblast syntaktických vztahů a větných členů) postrádá sémanticko-pragmatický přístup a nezaměřuje se na praktické užití znalostí v komunikaci (srov. Brádková, 1999; Čechová, 1993/1994; Hrbáček, 1998/1999, 1999/2000; Zimová, 1997/1998, 1998/1999; a celá diskuze na stránkách časopisu Český jazyk a literatura v 80. letech a národní konference Syntax a jej vyučovanie - Oravec, 1981; Vaňko, 2005).

V podstatě všechny tyto problematické okruhy se týkají spojnic mezi psychodidaktickým a ontodidaktickým zaměřením bádání v oborové didaktice češtiny. Ta, ačkoliv má velmi dlouhou tradici (srov. Šmejkalová, 2015b), takto orientovanými výzkumy př́liš nedisponuje. Jeden z prvních systematičtějších počinů v oblasti výzkumu jazykových prekonceptů žáka provedl tým vedený E. Hájkovou při řešení projektu Vztah kognitivních struktur žáka a struktur jazykového systému v procesu edukace českého jazyka, podpořeného GA ČR, $\mathrm{v}$ němž se řešitelé zabývali prekoncepty slova, jmenného rodu, slovesného času a zapojení slova do věty a výpovědi u žáků mladšího školního věku (Hájková et al., 2013, 2014). Z výsledků vyplynulo, že žák na prvním stupni má k dispozici celou řadu neuvědomělých jazykových poznatků, což ve své studii k valenci predikátu potvrdila také Šmejkalová (2012). 
Hájková (2013) ve své další studii ukazuje, že ignorace žákovského prekonceptu může být ve škole letitá a může být podporovaná nejen učiteli, ale také autory učebnic - konkrétně pojednává o tématu rozlišování vět podle postoje mluvčího ke skutečnosti a způsobu zprostředkování tohoto učiva žákům na 1. stupni základní školy; na tentýž problém opakovaně upozorňuje také J. Svobodová - srov. její vystoupení na konferenci Nové aspekty v didaktice mateřského jazyka v dubnu 2015 v Praze-Klánovicích.

Na základě obsahu učebnic, vlastních zkušeností autora jako středoškolského a vysokoškolského učitele a dokladů popisujících edukační realitu v českém jazyce (např. Šalamounová, 2013, 2015/2016, nebo Štěpáník, 2016) lze však konstatovat, že škola báze prekonceptů nevyužívá vůbec nebo jen minimálně, přestože je jednou z hlavních individuálních charakteristik každého učícího se jedince (Doulík \& Škoda, 2003). Žákům jsou často vnu covány hotové vyjadřovací formy, aniž by byla jakkoliv zužitkována jejich vlastní znalost jazyka - avšak „dětská/žákovská komunikační zkušenost je [...] rozhodující pro utvoření prvotní dětské/žákovské představy o určitém jazykovém jevu“ (Hájková et al., 2013, s. 9), resp. tedy prekonceptu. Přitom „učit to, co je přirozeně zvládáno, znamená zbavovat žáka komunikační jistoty, komunikačního sebevědomí" (Prouzová, 2010, s. 52).

\section{Oborové ukotvení studie - větný člen přívlastek}

Př́vlastek (atribut) je větný člen rozvíjející podstatné jméno v platnosti jakéhokoliv větného členu, je to člen závislý na skladebním substantivu. Jak se uvádí v Př́ŕruční mluvnici češtiny, jde o větný člen zcela specifický, nebot' „na rozdíl od podmětu, předmětu, př́íslovečného určení a doplňku není nikdy konstitutivním komponentem větné struktury (tj. není vázán na přísudek), nýbrž je členem nominální skupiny“ (Grepl, 2003, s. 490). Čechová (2011, s. 320) uvádí, že jde o nejfrekventovanější větný člen, který je navíc významově značně rozmanitý - Mluvnice češtiny 3 rozlišuje přívlastek valenční, determinační, př́vlastek u synkretických výrazů, kvantifikační a delimitační (Daneš, Hlavsa, \& Grepl, 1987, s. 127n.). Podle formy rozlišujeme přívlastek shodný a neshodný, dle funkce („aktuální referenční platnosti substantivní fráze" - Daneš et al., 1987, s. 157) se pak kvalitativní př́vlastek dělí na těsný (restriktivní) a volný (nerestriktivní; Grepl, 2003, s. 495). $\mathrm{V}$ př́padě posloupnosti (spojení) dvou nebo více navzájem nesouřadných přívlastků hovoříme o přívlastku postupně se rozvíjejícím, v prrípadě posloupnosti př́vlastků, mezi nimiž existuje koordinační nebo adordinační 
vztah, hovoříme o přílastku zmnoženém (ve škole několikanásobném; Daneš et al., 1987, s. 163-166). Pestrost způsobů vyjádření přívlastku ukázal V. Šmilauer v Novočeské skladbě (Šmilauer, 1966, s. 173n.), tu jsme také použili při designování našeho výzkumu.

\section{Popis výzkumu}

Cílem této studie je prozkoumat žákovo chápání vybraného větného členu, konkrétně přívlastku, po absolvování výuky syntaxe na základní škole. Pohybujeme se zde na pomezí všech tří transdidaktických pojmů, které jsme definovali výše. Žák každodenně užívá přívlastek, disponuje tedy jeho prekonceptem a umí jej prostřednictvím jazykové predstavy konkretizovat ve svých výpovědích. To znamená, že implicitně ví, v jaké komunikační situaci má př́ivlastek použít k naplnění svého komunikačního záměru, intuitivně správně vystihuje jeho funkci a postavení ve větě. Tímto způsobem se žák v pozici rodilého mluvčího - podílí na existenci a vývoji konceptu př́ívlastku ve svém jazyce. Po absolvování základní školy by měl být rovněž vybaven určitými znalostmi konceptu př́vlastek na úrovni metakognitivní; to znamená, že by měl př́ivlastek uvědoměle rozpoznávat v reálných výpovědích, měl by umět pojmenovat a charakterizovat různé druhy jeho uplatnění ve větách a měl by být schopen o přívlastku teoreticky (lingvisticky) uvažovat, především si tedy uvědomovat jeho funkci v komunikaci. Očekávané výstupy $\mathrm{v}$ tomto směru najdeme pochopitelně i v RVP ZV a dále jsou rozpracovány ve standardech pro základní vzdělávání. ${ }^{9}$

V našem výzkumu si klademe následující otázky:

1) Jak žák o přívlastku přemýšlí?

2) Jak škola (ne)přispívá k pochopení podstaty tohoto jazykového jevu (konceptu)?

3) Jak ve škole probíhá rozvoj komunikačně-syntaktické kompetence?

Zaměřili jsme se na zodpovězení výše uvedených otázek u žáků 1. ročníku střední školy, zjištovali jsme tedy stav po absolvování základního vzdělávání; výzkum byl proveden v červnu 2015. Pro výzkum jsme zvolili stratifikovaný

9 Např. očekávaný výstup RVP ZV ČJL-9-2-06 (Žák rozlišuje významové vztahy gramatických jednotek ve větě jednoduché i v souvětí), k němuž se váže indikátor ČJL-9-2-06.1 (Žák určí ve větách vyznačená slova jako větné členy; Holasová et al., 2011, s. 61). 
náhodný výběr vzorku celkem 8 žáků ze dvou tříd obchodní akademie v Praze 10, oboru ekonomické lyceum, vyučovaných touž učitelkou. Kritériem pro stratifikaci byl klasifikační stupeň v českém jazyce a literatuře za 1. pololetí daného školního roku - úmyslně jsme zvolili klasifikační rozpětí od stupně výborný až po stupeň dostatečný (dva žáci klasifikováni výborně, tři chvalitebně, dva dobře a jeden dostatečně). ${ }^{10}$ Syntax se na zmíněné škole dle ŠVP vyučuje až ve 3. ročníku, žákovo porozumění obsahu tedy nemohlo být nijak ovlivněno středoškolskou edukací - tuto skutečnost jsme rovněž ověřili rozhovorem s učitelkou. Vzorek byl konstruován graduálně - po rozhovoru s pátým subjektem bylo zřejmé, že subjekty vykazují obdobné odpovědi, u osmého žáka bylo dosaženo teoretické nasycenosti.

Ve výzkumu byla využita metoda individuálního řízeného rozhovoru nad cvičeními, která byla designována speciálně pro tento výzkum (Miovský, 2006; Doulík \& Škoda, 2008; Cohen, Manion, \& Morrison, 2011; Štěpáník, 2014; zadání otázek v těchto cvičeních viz dále). Úkoly ve cvičeních byly hierarchizovány tak, aby se postupovalo od obecného ke konkrétnímu, od celé šiřre problému k vybraným jevům. Žáci proto byli nejprve tázáni zcela obecným jazykem, až později jsme zavedli lingvistické termíny - jedině tak bylo možné nahlédnout myšlení žáků na skutečně prekonceptuální úrovni, aniž by měli pocit školní úlohy.

Rozhovory byly následně přepsány, kódovány a analyzovány. Použitá metodologie umožnila kvalitativní i kvantitativní pohledy na získaná data. Jako design výzkumu jsme využili zakotvené teorie - byla tedy ponechána volnost tomu, aby se ve zkoumané oblasti vynořilo to, co je v ní významné (Strauss \& Corbinová, 1999, s. 14).

10 Žáci z celého klasifikačního rozpětí byli vybráni s úmyslem ověřit, zda existuje vztah mezi školní klasifikací a schopností žáka-rodilého mluvčího přemýšlet o vlastním jazyce. Naším úmyslem nebylo zkoumat závislost úrovně prekonceptů na školní klasifikaci, a to už z toho důvodu, že v klasifikaci z českého jazyka a literatury na střední škole dominuje složka literární (vlastní zkušenost autora, rozhovor s učitelkou). Navíc z výsledků vyplývá, že schopnost o jazyce uvažovat není nijak závislá na klasifikačním stupni z českého jazyka, ale že klasifikace může mít podstatný vliv na motivaci žáka se jazykem zabývat a o jazyku přemýšlet. 


\section{$5 \quad$ Popis fází výzkumu a výsledky}

\section{1 Úloha A1, A2}

Cílem první úlohy bylo zjistit, jak žák o přívlastku přemýšlí: bude se po absolvování základní školy zaměřovat na větněčlenskou platnost daného výrazu ve větě, $\mathrm{k}$ čemuž by teoreticky již měl být vybaven, nebo si bude všímat pouze významu slov na základě svých životních zkušeností? Jinými slovy: bude $\mathrm{k}$ výrazům přistupovat metakognitivně (lingvisticky), $\mathrm{k}$ čemuž byl v předchozí etapě výuky veden, nebo intuitivně uživatelsky, čímž se ukáže, že přívlastek „splývá“ s ostatními větnými členy v celku určitého komunikačního záměru?

K tomu jsme použili následující věty, v nichž jsme zvýraznili (a) přívlastek neshodný (úloha A1) a (b) přívlastek shodný (úloha A2). Úkolem žáků bylo charakterizovat zvýrazněná slova z jakéhokoliv pohledu.

a) Skandál s opravenými testy z matematiky vyvolal v Cermatu smršt'.

b) Na podporu svého tvrzení uvedu jeden včerejší příklad.

Ukázalo se, že ve volném komentáři všichni žáci vysvětlují význam věty či zvýrazněných slov, asociují zkušenosti z běžného života, do nichž často zasahují emoce: „Tak matematika [znamená - pozn. S. Š.] určitě čísla, počítání, pak logický myšlení, pak nějaký vzorečky.“ „[...] testy prostě z algebry, z čísel i geometrii pod tím slovem si představím, prostě počty.“ „Z matematiky - první, co mě asi napadlo, pochopitelně předmět ve škole, který máme asi třikrát nebo čtyřikrát týdně, nedá se říct, že by mě nebavil, ani že by mě bavil třeba natolik, že bych se matematikou zabýval do hloubky." „Rozhodně mi to slovo [matematika - pozn. S. Š.] nejde." K př́vlastku shodnému uvedli žáci například: „Včerejší den je takovej menší pohled, že už to je minulost.“ "Když je někdo včerejší, tak že to bere ještě jakoby z pohledu minulosti.“ „Je to ňákej časovej údaj.“ „Hm, tak včerejšek, je to minulost. Co se stalo prostě včera a nemůžeme to vrátit." I když jsou žáci výzkumníkem pobízeni k jinému pohledu, přidržují se pouze hlediska významu.

Po položení otázky, jakou mají daná slova ve větě funkci, příp. fungují-li v daných větách v nějakých vztazích, resp. vstupují-li do nějakých vztahů s ostatními slovy ve větě, byli všichni žáci (i ti hůře prospívající) schopni vystihnout podstatu př́vlastku vlastními slovy: doplňuje; upřesňuje význam; dává smysl; objasňuje více; bliže specifikuje; rozvádí více jiné slovo; konkretizuje; dokresluje; podává bližší informaci; je to bonus k jinému slovu; prakticky by nemusel 
být. Z této skutečnosti usuzujeme, že $\mathrm{v}$ myslích žáků existuje prekoncept přívlastku, který dokáží verbalizovat na základě funkce, již v dané větě má. Pouze dva žáci však tento prekoncept př́mo označili termínem př́vlastek, oba pak ještě s dvěma dalšími žáky postihli vazbu na řídící člen - konstatovali, že přívlastek rozvíjí podstatné jméno.

\section{2 Úloha B}

Ve druhé úloze jsme žákům předložili větu vybranou z příručky Hrátky s češtinou (Čechová, Oliva, \& Nejedlý, 2007, s. 138): Včera jsem celý den kvůli té patálii se zlodějem na slib daný bratrovi ani nepomyslel. ${ }^{11} \mathrm{~V}$ této fázi jsme zavedli termín prrívlastek a zadali žákům úkol, aby ve zmíněné větě přívlastky označili.

Čtyři žáci okamžitě reagovali značně odtažitě, což se ukázalo jako významná zábrana volného uvažování. Byly u nich patrny panika a úzkost a zřejmý negativní postoj k učivu, jež výrazně snížily motivaci pro plnění úkolu, nebot' se projevilo přímé očekávání neúspěchu: „Ježišmarjá. Já ani nevim, co to je, já si to nepamatuju ze základky, to mi nikdy nešlo." (žákyně klasifikovaná chvalitebně); „Jelikož to neumim přesně to... To bude ta čtyřka z češtiny." (žák klasifikovaný dostatečně). Ačkoliv tito žáci byli v předchozím úkolu schopni vlastními slovy definovat, co daný větný člen ve větě „dělá“, jakou v ní má funkci, v podstatě tedy definovat pojem, nebyli po zavedení termínu pro daný pojem schopni přívlastky identifikovat.

Jeden žák (klasifikovaný dostatečně) od řešení této úlohy zcela ustoupil, u ostatních žáků se projevila změna myšlení v tom smyslu, že namísto hodnocení slov dle jejich funkce (jako u prvního úkolu) volili ve škole nabytý a zformalizovaný postup použitím otázky „Jaký, který, čí?“

Níže uvedené indexy ukazují, kolik žáků dané slovo určilo jako přívlastek:

Včera jsem celý ${ }_{6}$ den kvůli té ${ }_{3}$ patálii se zlodějem ${ }_{3}$ na ${ }_{1 \text { (sic!) }}$ slib daný $_{6}$ bratrovi $_{1}$ ani nepomyslel.

(Správné řešení: Včera jsem celý den kvůli té patálii se zlodějem na slib daný bratrovi ani nepomyslel.)

Z výsledku určení je zřejmé, že vyšší úspěšnosti žáci dosáhli u přívlastků shodných než u přívlastku neshodného, navíc vždy vyjádřených přídavným jménem shodujícím se s řídícím podstatným jménem, tedy u typických

11 Jsme si vědomi určité vykonstruovanosti či komunikační nepřirozenosti této věty, nicméně zvolili jsme ji úmyslně jako prototypický školní příklad, na němž žáci větný rozbor procvičují. 
„učebnicových“ příkladů. U jedné žákyně se projevil klasický miskoncept, že přívlastek shodný stojí před řídícím podstatným jménem a přívlastek neshodný za ním. Jedna žákyně používala kvazi-termín přívlastek „určitý“ a „neurčitý“, další při otázce, jak postupuje, když má přívlastek vyhledat, odpověděla, že je to „automatické“. Zarážející je označení předložky „na“ jako přívlastku - z rozhovoru vyplynulo, že tak žákyně učinila proto, že se předložka vztahuje k podstatnému jménu.

\section{3 Úloha C}

Záměrem poslední úlohy bylo zmapovat, do jaké míry jsou žáci schopni identifikovat přívlastky různě vyjádřené, a tedy prověřit hypotézu, že žáci mají přívlastek primárně spojen s přídavným jménem (aniž by si uvědomovali vazby př́vlastků vyjádřených jiným slovním druhem nebo by byli jinak vyjádřeným př́vlastkům ve výuce vystaveni atd.) - jinak řečeno prozkoumat míru petrifikace nejčastějšího miskonceptu, jímž výuka na základní škole žáky zatěžuje (vlastní zkušenost autora).

$\mathrm{K}$ tomu jsme vybrali čtrnáct krátkých vět s př́vlastky vyjádřenými různým způsobem (srov. Šmilauer, 1966, s. 173n.), pro ilustraci uved'me:

Pozdě do noci s námi zưstal jen dobrák matikářr.

Kdy byl u nás zrušen trest smrti?

Neměla by sis bráti Simoniny boty.

Jeden žák (klasifikovaný dostatečně) od řešení úkolu zcela ustoupil. Dvě žákyně uvažovaly o funkci větného členu a byly schopny odhlédnout od formy vyjádření. Napřr. u spojení dobrák matikář, které nepatř́ k úplně běžným příkladům, žákyně uvažuje, že „to je přídavný jméno, ale že prostě dává další informaci... třeba $\mathrm{k}$ tomu slovu matikář - že to dává $\mathrm{k}$ tomu další informaci [...], že to rozvíjí"; na druhou stranu tatáž žákyně pak zřejmě v analogii s tímto přesvědčením určuje v souvětí Podle dopisů, které nám chodí do redakce, budou sporné především seriály jako přívlastek slovo především. Pouze jeden žák si všímá vazby na řídící člen. Pět žáků mechanicky aplikuje otázkovou metodu („Jaký, který, čí?") - o její problematičnosti viz dále.

Nejvyšší úspěšnosti žáci dosáhli u prototypických př́ikladů - např. trest smrti, sklenice vína, cesta zpátky. Tyto položky určilo 5-6 žáků a nezáleželo na tom, jestli se jedná o př́ivlastky shodné či neshodné. Střední úspěšnost (4 žáci) 
jsme zaznamenali u př́íkladů, u nichž bylo možno použít otázku „Jaký?“ a odpověd' byla zřejmá - dobrák matikářr, Simoniny boty, ten den. ${ }^{12}$ Nejnižší úspěšnost pak bylo možno zaregistrovat u přívlastků vyjádřených vedlejší větou nebo infinitivem (touha vrátit se), u jmenných struktur s interponovaným dalším rozvíjejícím větným členem (Nemám odvahu se ho na to zeptat.) a netypické př́klady jako čtvrt hodiny ${ }^{13}$ či bruneta jako havran.

\section{Shrnutí výsledků a diskuze}

Při volném uvažování o slovech ve větě všichni žáci posuzovali význam slov na základě každodenních zkušeností, žádný si spontánně nevšiml jazykové utvářenosti věty. Všichni žáci byli však na požádání schopni vystihnout funkci přívlastků ve větě svými slovy. Je tedy zřejmé, že v mysli každého žáka existuje určitý prekoncept přívlastku, který si žák dokáže uvědomit a nějak na své úrovni popsat. Pouze dva žáci z osmi po absolvování jazykové výchovy na základní škole disponovali interpretačním rámcem, který jim umožnil obohatit prekoncept lingvistickým náhledem, tj. hlubším porozuměním pro příslušný koncept. $\mathrm{Z}$ toho vyplývá možnost formulovat hypotézu, že „typický“ žák v naší současné škole posuzuje jazykový fenomén primárně uživatelsky, lingvistický způsob myšlení je až sekundární. To považujeme za důležitý moment pro výuku, nebot' zdůrazňuje nutnost vždy hledat v každém jednotlivém tematickém celku mluvnického učiva komunikační přesahy.

Po zavedení termínu pro daný koncept polovina žáků reagovala odtažitě, nebyla schopna dále s pojmem pracovat, jejich myšlení jako by bylo ochromeno. Nebyli svou přirozenou jazykovou zkušenost schopni uplatnit a projevil se u nich blok vyvolaný edukací. Uvažování o pojmu na úrovni metajazyka a vyjadřování se na úrovni osvojeného termínu žákům evidentně činilo potíže zřejmě i z těch důvodů, o nichž píší Pavelková a kol. (2010, s. 43), když popisují, že se žáci pro studium českého jazyka cítí být málo nadaní, středně motivovaní a že učivo v českém jazyce považují za obtížné (český jazyk je ve zmíněném výzkumu žáky hodnocen dokonce jako nejobtížnější předmět na 2. stupni ZŠ). Takový závěr by potvrzovaly reakce žáka klasifikovaného z českého jazyka dostatečně - ten se ani nepokusil úlohy vyřešit - jeho motivace poklesla a př́mé očekávání neúspěchu vedlo ke snaze se mu vyhnout.

12 Otázky Jaké boty? (Simoniny boty), Jaký den? (ten den), které žáci užili, jsou ovšem pochybné, neadekvátní.

13 I zde se žák školsky (zcela nevhodně, až nečesky) ptá Jaká čtvrt? - Čtvrt hodiny. 
Většina ostatních žáků přistupovala k vyhledání přívlastku mechanicky (tradičně školsky) za využití otázkové metody. Spontánní definice vlastního prekonceptu z předchozí úlohy nevyužil žádný z žáků.

V úloze $C$ se pak projevilo, že, přestože žáci mají některé metajazykové znalosti (znají funkci přívlastku ve větě, někteří i jeho vazbu na řídící člen, případně i druhy přívlastku), transfer těchto znalostí je malý, zvláště u méně typických př́íkladů. Nerozhoduje forma přívlastku (shodný x neshodný), ale konkrétní př́klad, a především možnost u něj jednoduše uplatnit (ve škole tak často užívanou) otázkovou metodu (Jaká sklenice? - Sklenice vína; Jaký trest? - Trest smrti; Jaká cesta? - Cesta zpátky). ${ }^{14}$ Je patrné, že méně tradičním formám vyjádření přívlastku (viz výše ty, u nichž byla v úloze $C$ zaznamenána nejnižší úspěšnost) žáci ve výuce vystavováni nejsou. ${ }^{15}$

Důležité je rovněž uvědomovat si slovnědruhovou a větněčlenskou platnost výrazu - jedna z žákyň označila za přívlastek předložku „na“ s tím, že „rozvíjí podstatné jméno“. Úsudek, že přívlastek rozvíjí podstatné jméno a je na něm závislý, je správný, nicméně žákyně by měla z poučení o morfologii vědět, že předložka jako synsémantický slovní druh (tj. neplnovýznamový) nenese význam sama o sobě, ale nabývá ho až ve spojení se jménem - podle toho ve spojení se jménem také tvoří větný člen. Podílí se „na výstavbě větné, ale nesamostatně" (Čechová, 2011, s. 90), z čehož vyplývá, že sama o sobě nemůže být větným členem. U žákyně tedy nedochází $\mathrm{k}$ propojení poznatků a uvědomění si souvislostí, což poukazuje na to, že ve výuce, která k tomuto druhu ne-znalosti vede, nejsou jazykové jevy probírány ve vzájemných vztazích (tj. relačně), ale spíše jako izolované entity (tj. substančně) - že nejde ve výuce češtiny o výjimečný problém, jsme se zmínili výše.

14 Již od počátku navrhujeme vycházet ze sémantiky věty a otázkovou metodu vůbec nezavádět. Je-li totiž jednou zavedena, fixuje se $\mathrm{v}$ mysli žáka a žák přistupuje $\mathrm{k}$ identifikaci větných členů formálně. Nejlépe by bylo tedy vycházet z konceptu skladebních dvojic a vztahů ve větě a zkoumání, co je na daném členu závislé, resp. co ho rozvíjí - k této teorii srov. např. Šmilauerovy myšlenky z 50. let (Šmejkalová, 2015a, s. 298n.).

15 Pro úplnost dodejme, že mechanické uplatňování otázkové metody, ačkoliv v praxi tak časté, je didakticky chybné. Jak předvedla jedna žákyně ve větě Už se vydali na cestu zpátky?: „Už se vydali na cestu - jakou cestu - cestu zpátky - ale tam by to taky mohlo být příslovečný určení místa. Kam se vydali? Zpátky. Kam se vydali? Na cestu zpátky. Už se vydali na cestu. Jakou cestu? Na cestu zpátky. Tak to tam taky může být vobojí, ne?"Stěžejní je všímat si vazby na řídící člen (k tomu srov. též Štěpáník, 2016; Zimová, 2015/2016). 


\section{Závěr}

Zobecníme-li výsledky našeho výzkumu, na př́ikladu přívlastku jsme ukázali, že ve výuce češtiny jako mateřského jazyka narážíme na problém přirozeného vnímání jazyka a jeho gramatického popisu. Lze předpokládat, že se problém týká i jiných partií učiva české syntaxe a zřejmě i některých dalších oblastí v jiných rovinách popisu jazykového systému. Žák-rodilý mluvčí pravidla fungování jazyka přirozeně chápe, cítí, dokáže je na své úrovni i popsat a pojmenovat, disponuje prekoncepty jazykových jevů a schopností je konkretizovat $\mathrm{v}$ představách realizovaných promluvami.

Současný způsob výuky mateřštiny u nás však nedokáže tuto přirozenou jazykovou kompetenci žáka zužitkovat, nedochází k jejich propojení a nastává střet, který se projevuje mj. v emoční sféře. Ve školní praxi se pak setkáváme s tím, že výuka mateřského jazyka mnohdy připomíná výuku cizího jazyka. Soudíme, že je nezbytné přiblížit výuku češtiny prekonceptuálnímu vnímání jazyka a tím odstranit atomizaci učiva do úhrnu izolovaných poznatků - vždyt' jazyk funguje jako systém vzájemných vztahů. Zároveň je třeba ve výuce uplatňovat sémanticko-pragmatický př́stup a neustále zprostředkovávat využitelnost poznatků v komunikační praxi. Aby mohl být tento cíl realizován, je třeba extenzivního zkoumání v oblasti žákovského chápání jazykových fenoménů. Tyto poznatky pak bude moci didaktika českého jazyka využít při formování „nové“, na žáka orientované koncepce výuky, což bude zahrnovat revizi obsahu předmětu a způsobu jeho didaktického zprostředkování žákům.

Ukazuje se, že výuka syntaxe př́liš brzy zavádí terminologii - v situaci, kdy žák ještě nemá upevněny základní znalosti a dovednost komunikačně-syntaktického uvažování. Neuvědomuje si vztahy mezi jednotlivými slovy ve větě, není schopen rozeznat skladební dvojice, mnohdy ani které slovo v dané větě je a které není větným členem, jinými slovy: nedokáže myslet na úrovni metajazyka. Stále tak nebyla naplněna teze, kterou by měl mít na paměti každý zodpovědný učitel, jehož cílem není jen „probrat“ předepsané učivo, ale žáky skutečně něco naučit, totiž, že podmínkou postupu ve větném rozboru je zvládnutí základních poznatků (srov. též Šmilauer, 1977, s. 14).

Z různých příčin jsme v českém jazyce svědky zásadního rozporu mezi očekávanými a skutečně dosaženými výsledky výuky. Syntaktickému učivu je na 2. stupni ZŠ poskytován značný prostor (srov. rozsah učiva v učebnicích, 
vlastní zkušenost autora). Přitom z výzkumu vyplývá, že žáci poznatky ovládají nedostatečně, jen formálně. Lze tedy pozorovat zřetelný rozpor mezi projektovaným, realizovaným a dosaženým kurikulem (o tom také Janík et al., 2011). Zatímco RVP stanovuje očekávané výstupy komunikačně, výuka klade stále velký důraz na získávání lingvistických poznatků, které však žáci v konečném důsledku ovládají mezerovitě, formálně, pouze jako inertní znalosti, tj. znalosti nabývané čistě pro školní účely (Snowman, McCown, \& Biehler, 2009, s. 314). V realitě výuky tím dochází k problému tzv. odcizeného a utajeného poznávání (Slavík et al., 2011, s. 111-112), čehož varovným následkem je, že žáci mají o učivo nízký zájem, pocitují ho jako zbytečné a odtržené od vyjadřovacích potřeb (srov. např. Rysová, 2005/2006), jejich motivace a píle pro jeho studium je nízká a vnímaná obtížnost vysoká. Žáci spíše očekávají neúspěch a špatný prospěch (Pavelková et al., 2010). Při takových výsledcích edukace nelze očekávat, že by žáci byli schopni znalosti o jazykovém systému aktivně využívat $\mathrm{v}$ komunikační praxi, jak by tomu v ideálním př́ípadě mělo být.

Považujme tuto studii za velmi základní popis problému a návrh, kudy by se potenciální výzkum mohl ubírat. $\mathrm{K}$ dosažení vytčeného cíle a odstranění popsaných potíží je $\mathrm{v}$ oblasti žákovského jazykového prekonceptu třeba dalšího intenzivního i extenzivního zkoumání. Lze však doufat, že zvýšený ohled na žákovskou perspektivu $\mathrm{v}$ didaktickém př́ístupu $\mathrm{k}$ učivu může vést $\mathrm{k}$ pozitivním změnám $\mathrm{v}$ uplatnění poznatků didaktického výzkumu ve vzdělávací praxi, a tím přispět k didakticky kvalitnějšímu a pro žáky prospěšnějšímu zprostředkování obsahu ve výuce.

\section{Literatura}

Adam, R., Bozděchová L., Dittmann, R., \& Lehečková E. (2010/2011). Co neumějí studenti bohemistiky. Český jazyk a literatura, 61(1), 8-14.

Brádková, H. (1999). Význam sémantiky ve vyučování české gramatice. Jazykovědné aktuality, 36(zvláštní číslo), 34-36.

Cohen, L., Manion, L., \& Morrison, K. (2011). Research methods in education. Oxon: Routledge.

Čechová, M. (1993/1994). O potřebě integrace komunikační a systémové jazykové výuky. Český jazyk a literatura, 44(7-8), 158-162.

Čechová, M. (2011). Čeština - řeč a jazyk. Praha: SPN.

Čechová, M. (2011/2012). Zrušíme nejen větné rozbory? Český jazyk a literatura, 62(5), 237-241.

Čechová, M. (2013/2014). Smysl středoškolského studia češtiny ve stínu maturit. Český jazyk a literatura, 64(1), 1-6.

Čechová, M., Oliva, K., \& Nejedlý, P. (2007). Hrátky s češtinou. Praha: SPN. 
Čechová, M., \& Styblík, V. (1998). Čeština a její vyučování. Praha: SPN.

Daneš, F., Hlavsa, Z., \& Grepl, M. (1987). Mluvnice češtiny 3. Praha: Academia.

Dean, G. (2003). Grammar for improving writing and reading in the secondary school. London: David Fulton Publishers.

Dolník, J. (2010). Základné lingvistické otázky a spisovný jazyk. In M. Šimková (Ed.), Slova tvorba - dynamickost' (s. 21-28). Bratislava: Veda.

Doulík, P., \& Škoda, J. (2003). Tvorba a ověření nástrojů kvantitativní diagnostiky prekonceptů a možnosti jejího vyhodnocení. Pedagogika, 53(2), 177-189.

Doulík, P., \& Škoda, J. (2008). Diagnostika dětských pojetí a její využití v pedagogické praxi. Ústí nad Labem: UJEP.

Dvořák, K. (1997/1998). Stupeň schopnosti poznávat a vyjadřovat myšlenkové vztahy ve výpovědích. Český jazyk a literatura, 48(3-4), 67-73.

Gaux, C., \& Gombert, J. E. (1999). Implicit and explicit syntactic knowledge and reading in preadolescents. British Journal of Developmental Psychology, 17(2), 169-188.

Grepl, M. (2003). Př́ruční mluvnice češtiny. Praha: NLN.

Hájková, E. (2013). Učivo o větě na 1. stupni ZŠ. Didaktické studie, 5(2), 11-19.

Hájková, E., Hejlová, H., Janovec, L., Kucharská, A., Babušová, G., \& Höflerová, E. (2013). Čeština ve škole 21. století - III. Jazykové jevy v dětských prekonceptech. Praha: PedF UK v Praze.

Hájková, E., Hejlová, H., Janovec, L., Kucharská, A., Babušová, G., \& Höflerová, E. (2014). Čeština ve škole 21. století - IV. Výzkum edukačních podmínek jazykových jevü. Praha: PedF UK $\mathrm{v}$ Praze.

Hausenblas, K. (1965/1966). Větný rozbor, nebo nalepování vinětek? Český jazyk a literatura, 16(3), 207-213.

Höflerová, E. (2012). Konstruktivismus jako racionální opora didaktiky českého jazyka. In E. Hájková (Ed.), Čeština ve škole 21. století - II. Úvodní studie (s. 83-95). Praha: PedF UK v Praze.

Höflerová, E. (2015). Constructivism in teaching the mother tongue or how to teach the Czech language better to Czech-speaking children. Pedagogika, 65(5), 532-541.

Holasová, T., Altmanová, J., Hájková, E., Nedvědová, J., Koštál, Z., Šichová, J., ... Burdová, D. (2011). Standardy pro základní vzdělávání - český jazyk a literatura. Dostupné z http://www.msmt. cz/vzdelavani/zakladni-vzdelavani/standardy-pro-zakladni-vzdelavani-1.

Horecký, J. (1991). Jazykové vedomie. Jazykovedný časopis, 42(2), 81-88.

Hrbáček, J. (1998/1999). K rozboru syntaktických vztahů ve škole. Český jazyk a literatura, 49(1-2), 14-25.

Hrbáček, J. (1999/2000). Text a jeho rozbor ve škole. Český jazyk a literatura, 50(5-6), 109-116.

Chlup, O. (1958). Několik statí k základnímu učivu. Praha: SPN.

Janík, T. (2013). Od reformy kurikula k produktivní kultuře vyučování a učení. Pedagogická orientace, 23(5), 634-663.

Janík, T., Knecht, P., Najvar, P., Píšová, M., \& Slavík, J. (2011). Kurikulární reforma na gymnáziích: výzkumná zjištění a doporučení. Pedagogická orientace, 21(4), 375-415.

Janík, T., \& Slavík, J. (2009). Obsah, subjekt a intersubjektivita v oborových didaktikách. Pedagogika, 59(2), 116-135.

Janík, T., Slavík, J., Mužík, V., Trna, J., Janko, T., Lokajíčková, V., ... Zlatníček, P. (2013). Kvalita (ve) vzdělávání: obsahově zaměrený př́stup ke zkoumání a zlepšování výuky. Brno: MU. 
Jelemenská, P., Sander, E., \& Kattmann, U. (2003). Model didaktickej rekonštrukcie: Impulz pre výskum v odborových didaktikách. Pedagogika, 53(2), 190-201.

Jelínek, J. (1979). Úvod do teorie vyučování českému jazyku. Praha: SPN.

Jelínek, J., Těšitelová, M., \& Styblík, V. (1957). Vyučování českému jazyku v osmém postupném ročníku. Praha: SPN.

Kostečka, J. (2012a). Obrana centrálního hodnocení maturitních prací proti zlobivým jeho utrhačům. Učitelské noviny, 115(26), 17.

Kostečka, J. (2012b). Rekviem za státní maturitu z češtiny. Učitelské noviny, 115(31), 15.

Kucharská, A. (2012). Dětské prekoncepty a možnosti jejich sledování v oblasti jazykového systému. In E. Hájková (Ed.), Čeština ve škole 21. století - II. Úvodní studie (s. 43-57). Praha: PedF UK v Praze.

Locke, T. (Ed.). (2010). Beyond the grammar wars. Oxon: Routledge.

Miovský, M. (2006). Kvalitativní přístup a metody v psychologickém výzkumu. Praha: Grada.

Nippold, M. A., Hesketh, L. J., Duthie, J. K., \& Mansfield, T. C. (2005). Conversational versus expository discourse: A study of syntactic development in children, adolescents, and adults. Journal of Speech, Language, and Hearing Research, 48(5), 1048-1064.

Nippold., M. A., Frantz-Kaspar, M. W., Cramond, P. M., Kirk, C., Hayward-Mayhew, C., \& MacKinnon, M. (2014). Conversational and narrative speaking in adolescents: Examining the use of complex syntax. Journal of Speech, Language, and Hearing Research, 57(3), 876-886.

Oravec, J. (Ed.). (1981). Syntax a jej vyučovanie. Zborník referátov z konferencie. Nitra: PedF

Palečková, J., Tomášek, V., \& Basl, J. (2010). Hlavní zjištění výzkumu PISA 2009. Praha: ÚIV.

Pavelková, I., Škaloudová, A., \& Hrabal, V. (2010). Analýza vyučovacích předmětů na základě výpovědí žáků. Pedagogika, 60(1), 38-61.

Prouzová, R. (2010). Funkce přirozeného jazyka v procesu vzdělávání. Praha: Via Lucis.

Průcha, J. (1978). Jazykové vzdělání. Praha: Academia.

Průcha, J. (1983). Perspektivy vzdělání. Praha: SPN.

Průcha, J. (2011). Dětská řeč a komunikace. Praha: Grada.

Rysová, K. (2005/2006). Několik postřehů z výuky českého jazyka a literatury na SŠ. Český jazyk a literatura, 56(5), 232-234.

Slavík, J., \& Janík, T. (2005). Významová struktura faktu v oborových didaktikách. Pedagogika, 55(4), 336-353.

Slavík, J., Janík, T., Najvar, P., Švecová, Z., \& Minaříková, E. (2011). Kurikulární reforma na gymnáziích: od virtuálních hospitací k videostudiím. In T. Janík, P. Knecht, \& S. Šebestová (Eds.), Smíšený design v pedagogickém výzkumu: sborník příspěvků z 19. výroční konference České asociace pedagogického výzkumu (s. 31-38). Brno: Masarykova univerzita.

Slavík, J., Chrz, V., \& Štech, S. (2013). Tvorba jako způsob poznávání. Praha: Karolinum.

Slavík, J. (2014). K přehledové stati Jiř́ího Mareše: Hudební představy, hudební představivost a mentální reprezentace hudby - podněty k diskusi. Živá hudba, 2014(5), 1-11.

Slavík, J., Lukavský, J., Najvar, P., \& Janík, T. (2015). Profesní soud o kvalitě výuky: předem a následně strukturovaná reflexe. Pedagogika, 65(1), 5-33.

Snowman, J., McCown, R., \& Biehler, R. (2009). Psychology applied to teaching. Boston: Houghton Mifflin Company.

Strauss, A., \& Corbinová, J. (1999). Základy kvalitativního výzkumu: postupy a techniky metody zakotvené teorie. Boskovice: Albert. 
Svoboda, K. (1975). Stylizační výcvik ve spisovné češtině a rozvoj myšlení I a II. Praha: SPN.

Svoboda, K. (1977). Didaktika českého jazyka a slohu. Praha: SPN.

Svobodová, J., Jandová, E., \& Hubáček, J. (2002). Čeština pro učitele. Praha: Vade mecum Bohemiae.

Šalamounová, Z. (2013). Výuková situace: Když spojky nejen spojují aneb Ke komunikačnímu pojetí výuky gramatiky. Komenský, 137(3), 38-44.

Šalamounová, Z. (2015/2016). Když se algoritmy stanou pojistným mechanismem. Český jazyk a literatura, 66(1), 21-27.

Šmejkalová, M. (2010). Čeština a škola - úryvky skrytých dějin: český jazyk a jeho vyučování na středních školách, 1918-1989. Praha: Karolinum.

Šmejkalová, M. (2012). Teorie didaktických situací - nová výzva pro didaktiku morfologie českého jazyka. Didaktické studie, 4(1), 40-61.

Šmejkalová, M. (2015a). Praporu věren i ve ztraceném boji: Vladimír Šmilauer - život a dílo filologa (1895-1983). Praha: Academia.

Šmejkalová, M. (2015b). Didaktika českého jazyka. In I. Stuchlíková, \& T. Janík, et al., Oborové didaktiky: vývoj-stav - perspektivy (s. 17-40). Brno: MU.

Šmilauer, V. (1966). Novočeská skladba. Praha: SPN.

Šmilauer, V. (1977). Učebnice větného rozboru. Praha: SPN.

Štěpáník, S. (2014). Př́́klad výzkumu žákovských představ v české syntaxi. Pedagogická orientace, 24(1), 111-127.

Štěpáník, S. (2015). Konstruktivismus a jeho didaktické implikace ve vyučování českého jazyka. Nová čeština doma a ve světě, 2015(2), 11-22.

Štěpáník, S. (2016). Výuková situace: Transformace větného členu na větu a naopak v kontextu větného rozboru. Komenský, 140(4), 30-39.

Vachek, J. (Ed.). (1970). Teze předložené prvému sjezdu slovanských filologů v Praze 1929. In J. Vachek (Ed.), U základio pražské jazykovědné školy (s. 35-65). Praha: Academia.

Vaňko, J. (Ed.). (2005). Syntax a jej vyučovanie III. Zborník z medzinárodnej vedeckej konferencie. Nitra: FF Univerzity Konštantína Filozofa v Nitre.

Zimová, L. (1997/1998). Vyjadřování větných členů infinitivem jako problém didaktický. Český jazyk a literatura, 48(9-10), 205-211.

Zimová, L. (1998/1999). Způsoby vyjadřování podmětu jako problém didaktický. Český jazyk a literatura, 49(3-4), 63-67.

Zimová, L. (2005/2006). Když se řekne skladba... Český jazyk a literatura, 56(5), 209-214.

Zimová, L. (2011/2012). O potřebnosti větného rozboru. Českýjazyk a literatura, 62(5), 241-244.

Zimová, L. (2015/2016). Ještě jednou k výuce skladbě. Český jazyk a literatura, 66(4), 164-169.

\section{Autoři}

PhDr. Stanislav Štěpáník, Ph.D., Univerzita Karlova, Pedagogická fakulta, Katedra českého jazyka, M. D. Rettigové 4, 11639 Praha 1, e-mail: stanislav.stepanik@pedf.cuni.cz

doc. PaedDr. Jan Slavík, CSc., Univerzita Karlova, Pedagogická fakulta, Katedra primární pedagogiky, M. D. Rettigové 4, 11639 Praha 1, e-mail: jan.slavik@pedf.cuni.cz 


\title{
Pupil's preconceptions as the constitutive component of $\mathbf{L 1}$ instruction
}

\begin{abstract}
The aim of this empiric paper is to (1) introduce the pupil's preconception as a constitutive component of L1 instruction, (2) on the concrete example of the sentence element of grammatical modifier show that understanding the pupil's preconception as a key determinant of instruction is not only relevant, but truly necessary; (3) suggest which direction further research and instruction improvements might have. The first part defines the key concepts - notion, preconception, conception - and analyses their place in L1 instruction. Then it shows the critical areas in Czech language and Czech syntax instruction, the last part presents the authors' research. Through random stratified sampling a sample of pupils in the first year of upper secondary school was created. Through the method of individual interview using specially designed exercises pupils' preconceptions of the grammatical modifier were researched. The results suggest that pupils have the conception of the grammatical modifier and also low-achieving pupils are able to verbalize it and describe it precisely. However, after introducing terminology, with some pupils a bloc imposed by education and a clash between natural perception of language and its grammatical description appears. Pupils also start thinking differently - their spontaneous contemplations stop and they start using inappropriate mechanical strategies taught at school. The study also draws attention to the persisting problem - instruction introduces terminology too early and does not link it to the pupil's natural language competence and communication experience. Despite the unsatisfactory mastering of fundamental knowledge it advances, which creates the vicious circle of failure.
\end{abstract}

Keywords: notion, preconception, conception, didactics, Czech language, L1, syntax, clause element, grammatical modifier 